Original Research Paper

\title{
Microalgae Schizochytrium sp. in Feed for Piau Leporinus friderici
}

\author{
${ }^{1}$ Aline D.S. Prates, ${ }^{1}$ Marianne Schorer, ${ }^{1}$ Guilherme S. Moura, \\ ${ }^{2}$ Eduardo A.T. Lanna, ${ }^{3}$ Gustavo F. Castro and ${ }^{1}$ Marcelo M. Pedreira \\ ${ }^{1}$ Laboratory of Aquaculture and Aquatic Ecology, Federal University of the Jequitinhonha and Mucuri Valleys, \\ Highway MGT 367, km 583 Alto da Jacuba, $n^{\circ}$ 5000, zip code 30100-000 Diamantina, MG, Brazil \\ ${ }^{2}$ Laboratory of Nutrition of Aquatic Organisms, Federal University of Viçosa, Avenue Peter Henry Rolfs, \\ w/n - University Campus, Viçosa - MG, 36570-900 Viçosa, MG, Brazil \\ ${ }^{3}$ Laboratory of Animal Nutrition, Federal University of the Jequitinhonha and Mucuri Valleys, \\ Highway MGT 367, km 583 Alto da Jacuba, $n^{\circ}$ 5000, CEP 30100-000 Diamantina, MG, Brazil
}

\author{
Article history \\ Received: 18-06-2018 \\ Revised: 19-09-2018 \\ Accepted: 31-10-2018 \\ Corresponding Author: \\ Marianne Schorer \\ Laboratory of Aquaculture and \\ Aquatic Ecology, Federal \\ University of the Jequitinhonha \\ and Mucuri Valleys, Highway \\ MGT 367, km 583 Alto da \\ Jacuba, $\mathrm{n}^{\circ} 5000$, zip code \\ 30100-000 Diamantina, MG, \\ Brazil \\ Email: marianne.schorer@gmail.com
}

\section{Introduction}

The species Leporinus friderici, Bloch 1794 have a great commercial value because of their wellappreciated meat (Nomura, 1984). Several types of research on incorporating essential nutrients in fish feeds are a new way to food enrichment for human consumption (Li et al., 2009; Qiao et al., 2014; Kousoulaki et al., 2015).

It is known that the fish body protein and lipid profile can be adjusted according to diet and inclusion of polyunsaturated acid (PUFA) source, such as Docosahexaenoic Acid (DHA), found in microalgae, being an alternative to changes organoleptic caractheristics and improve the growth (LenihanGeels et al., 2013; Martins et al., 2013).

\begin{abstract}
The objective of the study was to evaluate the growth of piau (Leporinus friderici) juveniles fed with diet supplemented with different levels of Schizochytrium sp. One hundred and forty juveniles of $L$. friderici an 20 aquariums $(35 \mathrm{~L})$ at the density of 0.2 fish $\mathrm{L}^{-1}$, weighing and measuring $11.80 \pm 1.08 \mathrm{~g}$ and $9.68 \pm 0.31 \mathrm{~cm}$, respectively. The feeds were and supplemented with 0,10,20,30 and $40 \mathrm{~g}$ of Schizochytrium sp. . On the $60^{\text {th }}$ day, all juveniles were collected for measurement of food conversion, total length (cm), Specific Growth Rate (SGR) and Fulton's condition factor $(\mathrm{K})$. Also, the whole-body composition was analyzed for dry matter, mineral matter, crude protein, lipids, calcium and phosphorus. A linear effect $(\mathrm{p}<0.05)$ was observed for weight gain, weight, biomass, feed intake, SGR and K when Schizochytrium sp. was included in the feed. The levels of crude protein, calcium and phosphorus in juveniles had a linear decreasing effect $(\mathrm{p}<0.05)$ with the increase of Schizochytrium $\mathrm{sp}$. in the feeds. In brief, our results showed that $L$. friderici juveniles fed with artificial diets supplemented with Schizochytrium sp. had a better growth, with a
\end{abstract}

Keywords: Algae, Body Chemical Composition, Fatty Acid Source, Thraustochytriaceae
A several species of microalgae, as Schizochytrium sp., are identified as rich in carbohydrates, proteins, lipids and nutritionally valuable components (Sarker et al., 2016; Sathasivam et al., 2017). A practical way of enriching diets for captive-bred fish is the inclusion of microalgae, which can modify the lipid and protein profile of the animal muscle composition (Richmond, 2004; Li et al., 2009; Qiao et al., 2014). Rsearches with freshwater fish shows increased lipids and protein profile after the inclusion of microalgae in feed, improving fish growth (Qiao et al., 2014; Sarker et al., 2016), been an alternative to increase productive yield.

Thus, the objective of this study was to evaluate the growth and the body chemical profile of $L$. friderici juveniles fed with diets supplemented with different levels of the microalgae Schizochytrium sp. 


\section{Material and Methods}

The experiment was conducted indoors, in the city of Diamantina-MG, in Brazil $\left(18^{\circ} 15^{\prime}\right.$ south latitude, $43^{\circ} 36^{\prime}$ west longitude and $1.400 \mathrm{~m}$ above sea level), from September 12 to November 10 of 2015 (60 days). The research was carried out in accordance with the ethical standards and approved by the Ethics Committee on Animal Use (process $n^{\circ}$ 029/2016).

Prior to the experiment, fish were adapted to a trial for seven days, being fed a control artificial diet (without the inclusion of Schizochytrium sp.). Then, 140 juveniles were selected, weighed and measured $(11.80 \pm 1.08 \mathrm{~g}$ and $9.68 \pm 0.31 \mathrm{~cm}$, respectively). These juveniles were stocked in 20 aquariums $(35 \mathrm{~L})$ at a density of 0.2 fish $\mathrm{L}^{-1}$, or seven fish per tank. These aquariums were provided with aeration and controlled temperature.

An artificial feed was prepared and supplemented with $0,10,20,30$ and $40 \mathrm{~g}$ of Schizochytrium sp. $\mathrm{kg}^{-1}$ of feed (Table 1). All the diets were extruded (INBRAMAQ MX40) and beads were produced with a mean diameter of $2 \mathrm{~mm}$. Each treatment had four replicates, in a completely randomized design. The juveniles of $L$. friderici were fed ad libitum three times a day (10 am, 1 $\mathrm{pm}$ and $4 \mathrm{pm}$ ). The composition of the microalgae meal is shown in Table 2.

The aquariums were cleaned three times a week (Monday, Wednesday and Friday) to remove waste. Weekly, water quality parameters were measured, such as temperature $\left({ }^{\circ} \mathrm{C}\right), \mathrm{pH}$, dissolved oxygen $\left(\mathrm{mg} \mathrm{L}^{-1}\right)$ and conductivity $\left(\mu \mathrm{sm}^{-1}\right.$ ), using a multiparameter (U-50 Horiba). The concentrations of total ammonia, nitrite and nitrate $\left(\mathrm{mg} \mathrm{L}^{-1}\right)$ were measured according to (APHA, 2012) (method 4500).

On the $60^{\text {th }}$ day of experiment, the juveniles were anesthetized with eugenol solution $\left(120 \mathrm{mg} \mathrm{L}^{-1}\right)$, being measured for biomass $(\mathrm{g})$, feed intake $\left(\mathrm{g} \mathrm{day}^{-1}\right)$, weight $(\mathrm{g})$, weight gain $(\mathrm{g})$, feed conversion, total length $(\mathrm{cm})$, standard length $(\mathrm{cm})$, specific-growth rate $(\mathrm{SGR}=100$ $\left(\ln \mathrm{Pt}_{\mathrm{r}}-\ln \mathrm{Pt}_{\mathrm{i}}\right) \Delta \mathrm{t}^{-1}$, considering $\Delta \mathrm{t}$ the duration in days between samplings, $\mathrm{Pt}_{\mathrm{i}}$ the initial weight and $\mathrm{Pt}_{\mathrm{f}}$ the final weight of each replicate) and Fulton's condition factor $\left.\left(\mathrm{K}=\text { weight } \mathrm{x} \text { standard length }{ }^{-3}\right)^{*} 100\right)$. After the data were collected, the fish were euthanized with benzocaine hydrochloride as CONCEA (2013) recommendation.

Table 1: Composition and analysis of experimental diets (natural matter)

\begin{tabular}{|c|c|c|c|c|c|}
\hline \multirow[b]{2}{*}{ Ingredients (\%) } & \multicolumn{3}{|c|}{ Treatments $\left(\mathrm{g} \mathrm{kg}^{-1}\right)$} & \multirow[b]{2}{*}{ AS30 } & \multirow[b]{2}{*}{ AS40 } \\
\hline & 0 & AS10 & AS20 & & \\
\hline Soybean meal $45 \%$ & 29.03 & 29.03 & 29.03 & 29.03 & 29.03 \\
\hline Corn grain & 8.62 & 8.62 & 8.62 & 8.62 & 8.62 \\
\hline Rice bran & 24.00 & 24.00 & 24.00 & 24.00 & 24.00 \\
\hline Gluten 60 & 23.79 & 23.79 & 23.79 & 23.79 & 23.79 \\
\hline Dicalcium phosphate & 3.01 & 3.01 & 3.01 & 3.01 & 3.01 \\
\hline Calcitic limestone & 1.00 & 1.00 & 1.00 & 1.00 & 1.00 \\
\hline Soy oil & 5.00 & 4.50 & 4.00 & 3.50 & 3.00 \\
\hline Schizochytrium sp. ${ }^{1}$ & 0.00 & 1.00 & 2.00 & 3.00 & 4.00 \\
\hline Inert (Kaolin) & 4.00 & 3.50 & 3.00 & 2.50 & 2.00 \\
\hline Vitamin and mineral premix ${ }^{2}$ & 0.50 & 0.50 & 0.50 & 0.50 & 0.50 \\
\hline L- lysin & 0.48 & 0.48 & 0.48 & 0.48 & 0.48 \\
\hline Vitamin $\mathrm{C}$ & 0.05 & 0.05 & 0.05 & 0.05 & 0.05 \\
\hline Common salt & 0.50 & 0.50 & 0.50 & 0.50 & 0.50 \\
\hline Antioxidant & 0.02 & 0.02 & 0.02 & 0.02 & 0.02 \\
\hline \multicolumn{6}{|c|}{ Calculated and analyzed composition } \\
\hline Dry matter $(\%)$ & 89.63 & 89.32 & 89.70 & 89.51 & 90.32 \\
\hline Crude protein $(\%)$ & 32.48 & 32.77 & 32.51 & 32.14 & 32.17 \\
\hline Digestible energy (Kcal/Kg) & 3100.00 & 3100.00 & 3100.00 & 3100.00 & 3100.00 \\
\hline Crude fiber $(\%)$ & 3.91 & 3.91 & 3.91 & 3.91 & 3.91 \\
\hline Ethereal extract (\%) & 9.74 & 9.71 & 9.50 & 9.50 & 9.55 \\
\hline Total Calcium (\%) & 1.45 & 1.28 & 1.31 & 1.56 & 1.40 \\
\hline Total phosphorus (\%) & 1.64 & 1.61 & 1.66 & 1.69 & 1.69 \\
\hline Available phosphorus (\%) & 0.70 & 0.70 & 0.70 & 0.70 & 0.70 \\
\hline Total lysin $(\%)$ & 1.60 & 1.60 & 1.60 & 1.60 & 1.60 \\
\hline Linoleic acid $(\%)$ & 3.91 & 3.91 & 3.91 & 3.91 & 3.91 \\
\hline
\end{tabular}


Table 2: Nutritional composition of microalgae Schizochytrium sp. meal

\begin{tabular}{|c|c|}
\hline Nutritional composition & $(\%)$ \\
\hline Dry matter & 96.30 \\
\hline Crude protein & 19.22 \\
\hline Ethereal extract & 50.00 \\
\hline Crude fiber & 0.90 \\
\hline Ashes & 3.67 \\
\hline Phosphorus & 0.47 \\
\hline Calcium & 0.34 \\
\hline Fatty acids & $(\%)$ \\
\hline \multicolumn{2}{|l|}{ Saturated } \\
\hline Myristic (C14:0) & 3,86 \\
\hline Palmitic (C16:0) & 54,69 \\
\hline Margaric (C17:0) & 0,63 \\
\hline Stearic (C18:0) & 1,80 \\
\hline Arachidic (C20:0) & 0,28 \\
\hline \multicolumn{2}{|l|}{ Monounsaturated } \\
\hline Myristolic (C14:1n9) & 1,60 \\
\hline \multicolumn{2}{|l|}{ Polyunsaturated } \\
\hline Eicosapentaenoic - EPA (C20:5n3) & 0,28 \\
\hline Erucic $(\mathrm{C} 22: \ln 9)$ & 0,53 \\
\hline Docosadienoico (C22:2n6) & 0,43 \\
\hline Docosahexaenoico - DHA (C22:6n3) & 27,20 \\
\hline Other fatty acids ${ }^{(1)}$ & - \\
\hline Unidentified & 0,71 \\
\hline $\mathrm{EPA}+\mathrm{DHA}$ & 27,48 \\
\hline \multicolumn{2}{|c|}{ 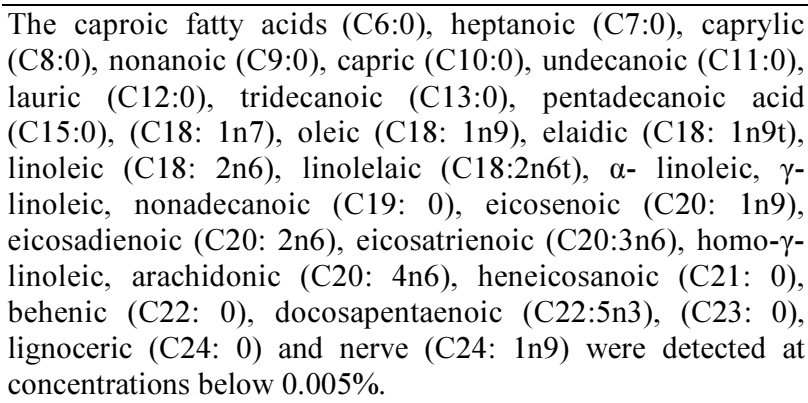 } \\
\hline
\end{tabular}

Fish whole-body and artificial diet proximate compositions were determined using the standard methods of AOAC (2012) (methods: 990.03 protein, 2003.05 lipids, 930.15 dry matter, 965.17 phosphorus and 968.08 calcium) at the Laboratory of Animal Nutrition of the Department of Animal Science. In the whole-body analysis, dry matter, mineral matter, crude protein, lipids, calcium and phosphorus contents were determined. All the analyses were carried out in duplicates.

Means and standard deviations were calculated for water quality parameters and characterization of the culture environment. To evaluate the effects of the inclusion of Schizochytrium sp. in the fish diets, the growth parameters and body chemical composition data were analyzed by ANOVA and linear regression, using the SigmaStat 3.5 software (Systat Software Inc.).

\section{Results}

The water quality parameters in the tanks were maintained constant throughout the entire experiment by controlled aeration and temperature (Table 3 ).

Table 3: Water quality parameters during the experimental period, 56 days, of Leporinus. friderici juveniles fed with different levels of Schizochytrium sp.

\begin{tabular}{lrl}
\hline Parameters & Mean & CV (\%) \\
\hline Temperature $\left({ }^{\circ} \mathrm{C}\right)$ & 27.340 & 3.39 \\
pH & 7.340 & 2.36 \\
Dissolved oxygen $\left(\mathrm{mg} \mathrm{L}^{-1}\right)$ & 4.850 & 3.97 \\
Total ammonia $\left(\mathrm{mg} \mathrm{L}^{-1}\right)$ & 0.020 & 3.53 \\
Nitrite $\left(\mathrm{mg} \mathrm{L}^{-1}\right)$ & 0.001 & 2.98 \\
Nitrate $\left(\mathrm{mg} \mathrm{L}^{-1}\right)$ & 0.910 & 4.52 \\
Conductivity $\left(\mu \mathrm{Sm} \mathrm{cm}{ }^{-1}\right)$ & 14.100 & 3.58 \\
\hline
\end{tabular}

Table 4: Performance of Leporinus friderici juveniles fed with diets supplemented with Schizochytrium sp., during 56 days

\begin{tabular}{|c|c|c|c|c|c|c|c|c|c|}
\hline \multirow[b]{2}{*}{ Parameters } & \multicolumn{5}{|c|}{ Schizochytrium sp. inclusion level $\left(\mathrm{g} \mathrm{kg}^{-1}\right)$} & \multirow[b]{2}{*}{ CV (\%) } & \multicolumn{3}{|c|}{ P-value ${ }^{1,2}$} \\
\hline & 0 & 10 & 20 & 30 & 40 & & $\mathrm{~L}$ & Q & $\mathrm{LF}$ \\
\hline Initial weight $(\mathrm{g})$ & 11.50 & 12.10 & 12.00 & 11.50 & 11.90 & 2.40 & 0.076 & 0.926 & 0.124 \\
\hline Weight gain $(g)^{1}$ & 41.90 & 45.70 & 69.90 & 71.50 & 86.10 & 28.19 & 0.004 & 0.910 & 0.013 \\
\hline Weight $(g)^{2}$ & 53.40 & 57.80 & 51.70 & 55.20 & 61.20 & 9.16 & 0.004 & 0.896 & 0.017 \\
\hline Total length $(\mathrm{cm})$ & 10.64 & 10.56 & 10.67 & 10.38 & 10.33 & 1.46 & 0.514 & 0.704 & 0.096 \\
\hline Biomass $(\mathrm{g})^{3}$ & 256.80 & 357.50 & 476.20 & 545.20 & 665.60 & 34.63 & 0.003 & 0.975 & 0.132 \\
\hline Feed intake $(g)^{4}$ & 61.40 & 68.90 & 89.50 & 87.00 & 96.50 & 18.37 & 0.001 & 0.264 & 1.340 \\
\hline Food conversion & 2.30 & 1.60 & 1.30 & 1.20 & 1.10 & 32.32 & 0.097 & 0.824 & 0.123 \\
\hline Specific growth rate $\left(\text { day }^{-1}\right)^{5}$ & 3.40 & 4.10 & 6.10 & 6.30 & 7.80 & 32.10 & 0.003 & 0.919 & 0.010 \\
\hline Fulton's condition factor ${ }^{6}$ & 4.60 & 5.50 & 6.40 & 7.20 & 7.60 & 19.62 & 0.008 & 0.730 & 0.070 \\
\hline
\end{tabular}

${ }^{1} \mathrm{~L}$ and $\mathrm{Q}-$ effects of linear and quadratic order concerning the inclusion of Schizochytrium sp. in the diet.

${ }^{2} \mathrm{LF}$ - lack of fit

${ }^{3} \hat{Y}=41.54+1.108 \times\left(r^{2}=0.952\right)$

${ }^{4} \hat{Y}=41.038+1.184 \times\left(\mathrm{r}^{2}=0.953\right)$

${ }^{5} \hat{Y}=257.76+10.35 \times\left(r^{2}=0.995\right)$

${ }^{6} \hat{Y}=61.540+2.905 \times\left(\mathrm{r}^{2}=0.990\right)$

${ }^{7} \hat{Y}=3.47+1.212 \times\left(\mathrm{r}^{2}=0.953\right)$

${ }^{8} \hat{Y}=4.567+0.1068 \mathrm{x}\left(\mathrm{r}^{2}=0.998\right)$ 
Table 5: Body chemical analysis of Leporinus friderici juveniles fed with diets supplemented with Schizochytrium sp., during 56 days Treatments $\left(\mathrm{g} \mathrm{kg}^{-1}\right)$

\begin{tabular}{lllllll} 
Nutrients & Control & AS10 & AS20 & AS30 & CV $(\%)$ \\
\hline DM $(\%))^{* 1}$ & $89.9 \pm 0.13$ & $90.5 \pm 0.68$ & $90.9 \pm 0.69$ & $91.1 \pm 0.14$ & 1.32 \\
MM (\%) & $13.61 \pm 0.01$ & $14.41 \pm 0.01$ & $15.61 \pm 0.13$ & $13.87 \pm 0.01$ & $12.84 \pm 0.26$ \\
L $(\%)^{* 2}$ & $19.8 \pm 0.20$ & $19.9 \pm 0.26$ & $19.9 \pm 0.13$ & $20.0 \pm 2.07$ & $22.1 \pm 2.43$ \\
CP $(\%)^{* 3}$ & $56.7 \pm 0.02$ & $60.7 \pm 0.02$ & $59.9 \pm 0.02$ & $60.7 \pm 0.01$ & $56.8 \pm 0.04$ \\
Ca $(\%)^{* 4}$ & $4.85 \pm 0.001$ & $4.44 \pm 0.001$ & $4.47 \pm 0.001$ & $4.34 \pm 0.001$ & $4.25 \pm 0.001$ \\
P $(\%)$ & $7.73 \pm 0.07$ & $7.74 \pm 0.03$ & $7.75 \pm 0.03$ & $7.03 \pm 0.02$ & $7.31 \pm 0.01$ \\
\hline
\end{tabular}

DM - Dry Matter. MM - Mineral Matter; L - Lipids; CP - Crude Protein; Ca - Calcium; P - Phosphorous;

${ }^{1}$ Linear effect: $\mathrm{Y}=-0.900+0.00355 \mathrm{x} ; \mathrm{R}^{2}=0.274$

${ }^{2}$ Linear effect: $\mathrm{Y}=1.787+0.00780 \mathrm{x} ; \mathrm{R}^{2}=0.971$

${ }^{3}$ Quadratic effect: $\mathrm{Y}=56.621+0.2846 \mathrm{x}-0.0079 \mathrm{x}^{2} ; \mathrm{R}^{2}=0.794$

${ }^{4}$ Linear effect: $\mathrm{Y}=4.86-0.013 \times\left(\mathrm{R}^{2}=0.802\right)$

An increasing linear effect $(\mathrm{p}<0.05)$ was observed for weight gain, weight, biomass, feed intake, SGR and K (Table 4) when Schizochytrium sp. was included in the artificial diets of $L$. friderici juveniles.

No differences $(\mathrm{p}>0.05)$ were observed for dry matter, mineral matter and lipids of $L$. friderici juveniles (Table 5). Still, with the increase of Schizochytrium $\mathrm{sp}$. in the diets, crude protein, calcium and phosphorus levels in juveniles had a linear decreasing effect $(p<0.05)$.

\section{Discussion}

The water quality parameters were maintained constant throughout the experiment period, falling within the ranges recommended for tropical species (Boyd and Tucker, 2014) and for Leporinus species (Sipaúba Tavares and Magalhães-Santeiro, 2013), thus not compromising the development of $L$. friderici juveniles.

Weight gain, weight, biomass, feed intake, SGR and $\mathrm{K}$ increased as the amount of Schizochytrium sp. included in the diets of $L$. friderici juveniles was raised. Freshwater fishes inhabit environments that are poor in polyunsaturated fatty acids, mainly docosahexaenoic acid; therefore, through an evolutionary pressure, they are able to retain the content produced endogenously (Tocher, 2010), which explains the efficient assimilation of Schizochytrium sp. in this experiment.

Algae inclusion in feeds had no influence on juvenile total length and food conversion. Sarker et al. (2016) also observed a low feed conversion in tilapia fed the same algae species, but with no differences in total length. Likewise, river prawns are known to have a better feed conversion when supplemented with Schizochytrium sp., but again with no effect on total length (Kangpanich and Senanan, 2015).

The microalgae Schizochytrium sp. can enhance the efficiency of nutrient absorption by the gastrointestinal tract since its content of fatty acids improves digestion, which has contributed to $L$. friderici juvenile growth. Similarly, Sarker et al. (2016) noted that tilapia fed diets supplied with Schizochytrium sp. had an improvement in weight gain and weight. Likewise, Hoestenberghe et al. (2016) also observed a higher weight gain in jade perch juveniles (Scortum barcoo). According to $\mathrm{Li}$ et al. (2009), the addition of $1.0 \mathrm{~g}$ $\mathrm{kg}^{-1}$ of dried microalgae (Schizochytrium sp.) in the diet of channel catfish (Ictalurus punctatus) promoted weight gain when compared to control artificial diets (without the microalgae). Moreover, (Li et al., 2009; Santos et al., 2015) reported increases in weight gain and biomass when Schizochytrium sp. was added in the diets of Nile tilapia (Oreochromis niloticus) and catfish (I. punctatus), respectively.

The dietary inclusion of Schizochytrium sp. microalgae increased feed intake of $L$. friderici juveniles, as observed for Atlantic salmon juveniles (Salmo salar) by Kousoulaki et al. (2015). Conversely, tilapia juveniles had a decrease in feed intake with an increasing inclusion of the microalgae (Sarker et al., 2016). As in this study, channel catfish had a greater feed intake when Schizochytrium sp. was included in the feed (Li et al., 2009).

The SGR of $L$. friderici juveniles increased as the levels of microalgae was raised in the diets, as already observed for sea cucumbers and prawns fed diets supplied with Schizochytrium sp. (Kangpanich and Senanan, 2015; Md et al., 2017). Yet, for freshwater fishes, the addition of Schizochytrium sp. in the diet had no influence on SGR (Sarker et al., 2016; Qiao et al., 2014); yet the use of microalgae oil (Crypthecodinium cohnii and Schizochytrium sp.) in diets reduced SGR in gilthead sea bream (Sparus aurata) (Ganuza et al., 2008). Despite these reports, SGR studies in fish fed microalgae are still scarce.

Fulton's condition factor $(\mathrm{K})$ is the ratio between body weight and length; it expresses the degree of well-being and feeding of fish in a previous season (N'da et al., 2016). This factor remained similar among the additional levels of Schizochytrium sp. in the diet, showing a linear effect, thus indicating that fish wellbeing was increased with the inclusion of this organism. 
The values observed in this study were higher than those reported in the literature (Guidelli et al., 2011; Nascimento et al., 2012), suggesting that the culture conditions were adequate for $L$. friderici juveniles. According to Adite et al. (2017), relatively high condition factors, indicated by $\mathrm{K}$ factor, promoted a perfect establishment of Chrysichthys nigrodigitatus in the aquatic environment they were growing.

The L. friderici juveniles have an improved dry matter and lipids levels in the whole-body when the supplementation of Schizochytrium sp. was increased and the level of protein was greater with the inclusion between 10 to $30 \mathrm{~g}$ of Schizochytrium sp. kg ${ }^{-1}$ in the feed. The increase of the corporal dry matter and protein, with the elevation of the levels of Schizochytrium sp. was directly related to $L$. friderici growth, with the increase in weight gain, biomass and SGR.

Sarker et al. (2016) also observed higher levels of body protein in juveniles of tilapia and consequently an increase in weight gain after feeding with Schizochytrium sp. The level of body protein also increased in juveniles of Paralichthys olivaceus fed with diets enriched with Schizochytrium sp. and Nannochloropsis sp. (Qiao et al., 2014). Juveniles of the channel catfish fed with diets enriched with Schizochytrium sp. had no significant difference in the contents of protein, lipids and moisture in fillet (Li et al., 2009), may be associated with the food habit of the species. Microalgae are a source of protein and lipids (Fleurence, 1999; Guccione et al., 2014) for fish species.

The increase of the body protein content in $L$. friderici, since proteins possess excellent amino acid scores and digestibility characteristics for humans, is a productive advantage and the enrichment of fish meat with lipids sources, as DHA, makes it a functional food for human health.

Contents of calcium in the body chemical profile of L. friderici decreased linearly with the inclusion of Schizochytrium sp. in the diet. Perhaps, the saponification reaction (Lehninger et al., 2008) between fatty acids in microalgae and this mineral in the gut of the juvenile impairing the digestion and metabolism of this mineral, hence causing the lower quantities found in the fish body composition.

\section{Conclusion}

Juveniles of Leporinus friderici fed with artificial diets supplemented with increasing levels of Schizochytrium sp. have better growth and changes in it the body chemical profile.

\section{Acknowledgment}

To CAPES, CNPq, and FAPEMIG (CICT 008/2016) for granting the scholarship, to Banco do Nordeste do Brasil (BNB/FUNDECI 2012/324), for financial support.

\section{Author's Contributions}

Prates, A.D.S.: Was the one who carried out the experimental part of the experiment, as well as the writing of his dissertation of Master.

Schorer, M.: Is the corresponding author, and was responsible for the new writing, research, English translation and corrections suggested by the reviewers.

Moura, G.S. and E.A. Lanna: Were the ones that gave the idea of this study bringing the microalga to our laboratory.

Gustavo F. Castro: Assisted in the laboratory analyzes of biotechnology.

Pedreira, M.M.: Was the supervisor of the dissertation and Master, and assisted in the writing and review of the article.

\section{Ethics}

The authors will address any ethical issues that may arise after the publication of this manuscript.

\section{References}

Adite, A., H.M.A.G. Gbaguidi and M. Ibikounle, 2017. Growth patterns and Fulton's condition factor of the silver catfish Chrysichthys nigrodigitatus (Actinopterygii: Siluriformes: Claroteidae) from a sand-dragged man-made lake of Benin. African J. Agr. Res., 12: 2283-2294.

DOI: $10.5897 / A J A R 2017.12375$

AOAC, 2012. Official Methods of Analysis. 19th Ed., AOAC International, Arlington, VA, USA, ISBN-10: 0-935584-77-3, pp: 1884.

APHA, 2012. Standard Methods for the Examination of Water and Wastewater. 22nd Ed., APHA, Washington, DC, USA, SBN-10: 9780875530130, pp: 1325.

Boyd, C.E. and C.S. Tucker, 2014. Handbook for Aquaculture Water Quality. 1st Edn., Crasftmaster Printers, Auburn, AL, USA, ISBN-10: 9780692221877, pp: 439.

CONCEA, 2013. Diretriz Brasileira para o Cuidado e a Utilização de Animais para Fins Científicos e Didáticos - DBCA. Portaria ${ }^{\circ} 465$.

Fleurence, J., 1999. Seaweed proteins: Biochemical, nutritional aspects and potential uses. Trends Food Sci. Technol., 10: 25-28.

Ganuza, E., T. Benitez Santana, E. Atalah, O. Vega Orellana, R. Ganga and M.S. Izquierdo, 2008. Crypthecodinium cohnii and Schizochytrium sp. as potential substitutes to fisheries-derived oils from seabream (Sparus aurata) microdiets. Aquaculture, 277: 109-116.

DOI: 10.1016/j.aquaculture.2008.02.005 
Guccione, A., N. Biondi, G. Sampietro, L. Rodolfi and N. Bassi et al., 2014. Chlorella for protein and biofuels: From strain selection to outdoor cultivation in a Green Wall Panel photobioreactor. Biothecnol. Biofuels, 7: 84-84. PMID: 24932216

Guidelli, G., W.L.G. Tavechio, R.M. Takemoto, G.C. Pavanelli, 2011. Relative condition factor and parasitism in anostomid fishes from the floodplain of the Upper Paraná River, Brazil. Vet. Parasit., 177: 145-151. DOI: 10.1016/j.vetpar.2010.11.035

Hoestenberghe, S.V., C. Fransman, T. Luyten, D. Vermeulen and I. Roelants et al., 2016. Schizochytrium as a replacement for fish oil in a fishmeal free diet for jade perch, Scortum barcoo (McCulloch and Waite). Aquac. Res., 47: 1747-1760. DOI: $10.1111 /$ are.12631

Kangpanich, C. and W. Senanan, 2015. Effects of Schizochytrium sp. on growth performance and survival rate of giant freshwater prawn, Macrobrachium rosenbergii (De Man). J. Agr. Technol., 11: 1337-1348.

Kousoulaki, K., T.K.K. Østbye, A. Krasnov, J.S. Torgersen and T. Mørkøre et al., 2015. Metabolism, health and fillet nutritional quality in Atlantic salmon (Salmo salar) fed diets containing n-3-rich microalgae. J. Nutr. Sci. DOI: 10.1017/jns.2015.14

Lehninger, A.L., D.L. Nelson and M.M. Cox, 2008. Lehninger Principles of Biochemistry. 5th Edn., Freeman, W. H., New York, ISBN-10: 978-1429234146, pp: 1328.

Lenihan-Geels, G., K. S. Bishop and L. R. Ferguson, 2013. Alternative sources of omega-3 fats: can we find a sustainable substitute for fish? Nutrients, 5: 1301-1315. DOI: 10.3390/nu5041301

Li, M.H., E.H. Robinson, C.S. Tucker, B.B. Manning and L. Khoo, 2009. Effects of dried algae Schizochytrium sp., a rich source of docosahexaenoic acid, on growth, fatty acid composition and sensory quality of channel catfish Ictalurus punctatus. Aquaculture, 292: 232-236. DOI: $10.1016 /$ j.aquaculture.2009.04.033

Martins, D.S., I. Custodio, L. Barreira, H. Pereira, R. Bem-Hamadou, J. Varela, K.M. Abu-Salah, 2013. Alternative sources of n-3 long-chain polynsaturated fatty acids in marine microalgae. Marine Drugs, 11: 2259 - 2281. DOI: $10.3390 / \mathrm{md} 11072259$

Md, A., F. Jin, J.K. Choi, U.C. Jeong and S.J. Kang, 2017. Effects of marine microalgae (Schizochytrium sp.) in prepared feeds on growth and survival rate of juvenile sea cucumber Apostichopus japoncus. Am. Sci. Res. J. Eng. Technol. Sci., 30: 325-337.
N'da, A.S., K. Gervais N'zi, B. Siaka, E.P. Kouamelan and V. N'douda, 2016. Length - weight relationship, condition factor and feeding habits of Brycinus leuciscus (Günther, 1867) (Characidae) in bagoe river, cote d'ivoire. Int. J. Applied Biol. Pharmac. Technol., 7: 161-168.

Nascimento, W.S., A.S. Araújo, N.T. Chellappa and S. Chellappa, 2012. Reproductive strategy of Leporinus piau (Fowler, 1941), a neotropical freshwater fish from the semi-arid region of Brazil. J. Applied Ichth., 29: 8-880. DOI: 10.1111/jai.12020

Nomura, H., 1984. Dicionário dos peixes do Brasil. 1st Edn., Brazil, pp: 482.

Qiao, H., H. Wang, Z. Song, J. Ma and B. Li et al., 2014. Effects of dietary fish oil replacement by microalgae raw materials on growth performance, body composition and fatty acid profile of juvenile olive flounder, Paralichthys olivaceus. Aquac. Nu.t, 20: 646-653. DOI: 10.1111/anu.12127

Richmond, A., 2004. Handbook of Microalgal Culture: Biotechnology and Applied Phycology. 1st Edn., Blackwell Science, Ames, IA, USA, ISBN-10: 0-632-05953-2. pp: 565.

Santos, S.K.A., G.S. Moura, M.M. Pedreira, A.D.S. Prates and A.L. Ferreira et al., 2015. Microalga Schizochytrium sp. em rações para tilápia do Nilo. Cad Ciênc Agr., 7: 75-79.

Sarker, P.K., A.R. Kapuscinski, A.J. Lanois, E.D. Livesey and K.P. Bernhard et al., 2016. Towards sustainable aquafeeds: complete substitution of fish oil with marine microalga Schizochytrium sp. improves growth and fatty acid deposition in juvenile Nile tilapia (Oreochromis niloticus). Plus One, 11: 1-17. DOI: 10.1371/journal.pone.0156684

Sathasivam, R., R. Radhakrishnan, A. Hashem and E.F. Abd_Allah, 2017. Microalage metabolites: A rich source for food and medicine. Saudi J. Biol. Sci. DOI: $10.1016 /$ j.sjbs.2017.11.003

Sipaúba Tavares, L.H. and R. Magalhães-Santeiro, 2013. Fish farm and water quality management. Acta Sci. Biol. Sci., 35: 21-27.

DOI: $10.4025 /$ actascibiolsci.v35i1.10086

Tocher, D.R., 2010. Fatty acid requirements in ontogeny of marine and freshwater fish. Aquac. Res., 41: 717-732. DOI: $10.1111 / \mathrm{j} .1365-2109.2008 .02150 . \mathrm{x}$ 